
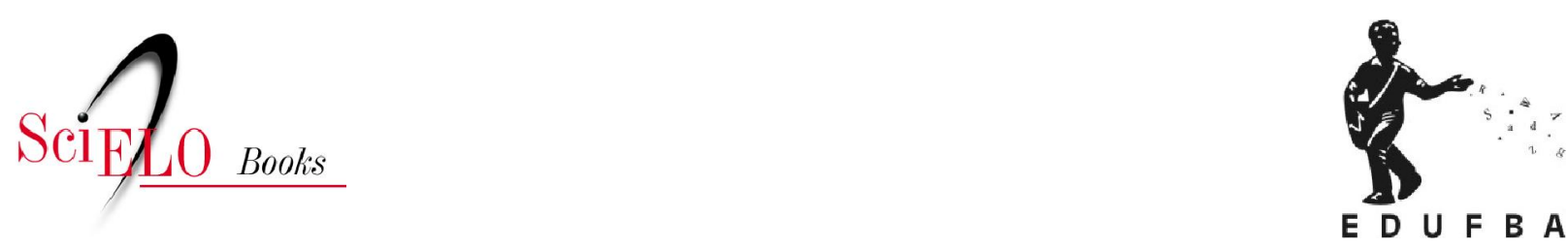

\title{
Parte II: Resistência e legalidade O esteio da ordem: comunistas, greves e sindicatos no Brasil (1945- 1948)
}

Carlos Zacarias de Sena Júnior

SciELO Books / SciELO Livros / SciELO Libros

SENA JÚNIOR, C.Z., ed. O esteio da ordem: comunistas, greves e sindicatos no Brasil (1945-1948). In: Capitulos de história dos comunistas no Brasil [online]. Salvador: EDUFBA, 2016, pp. 155-174. ISBN: 978-85-232-1873-7. https://doi.org/10.7476/9788523218737.0009.

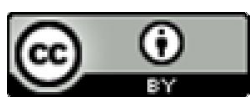

All the contents of this work, except where otherwise noted, is licensed under a Creative Commons Attribution 4.0 International license.

Todo o conteúdo deste trabalho, exceto quando houver ressalva, é publicado sob a licença Creative Commons Atribição 4.0.

Todo el contenido de esta obra, excepto donde se indique lo contrario, está bajo licencia de la licencia Creative Commons Reconocimento 4.0. 


\title{
O esteio da ordem: comunistas, greves e sindicatos no Brasil (1945-1948)
}

\author{
Carlos Zacarias de Sena Júnior
}

As grandes questões da liberdade política e da luta de classes são resolvidas em última análise unicamente pela força e nós devemos preocupar-nos com a organização e preparação desta força e com o seu emprego activo, não somente defensivo, mas também ofensivo. [...] Entrámos agora, indubitavelmente, numa nova época; iniciou-se um período de convulsões e revoluções e políticas. Num período como o que a Rússia está a atravessar é intolerável que nos limitemos aos velhos chavões. É preciso propagandear a ideia da acção a partir de cima, é preciso que nos preparemos para as acções mais enérgicas, ofensivas, é preciso estudaras condições e as formas dessas acções.

Lenin, As duas tácticas da social-democracia na revolução democrática

No desenvolvimento do Risorgimento, o chamado Partido da Ação tinha uma atitude 'paternalista' e, por isto, não conseguiu, a não ser em medida muito limitada, pôr as grandes massas populares em contato com o Estado. O chamado 'transformismo' é tão-somente a expressão parlamentar do fato de que o Partido da Ação é incorporado molecularmente pelos moderados e as massas populares são decapitadas, não absorvidas no âmbito do novo Estado.

Gramsci, Cadernos do cárcere (Caderno 19, o Risorgimento) 
Nos estertores da Segunda Guerra Mundial, enquanto a perspectiva de “coexistência pacífica” entre a União das Repúblicas Socialistas Soviéticas (URSS) e as democracias ocidentais era uma possibilidade, a aliança com a dita "burguesia progressista" no Brasil era mais do que necessária para os comunistas. Enquanto os ventos da Guerra Fria ainda não haviam soprado e uma onda de greves alcançava os trabalhadores brasileiros ajudando a corroer a ditadura do Estado Novo, o Partido Comunista teve algum êxito com a sua tática de antifascismo e de União Nacional que implicava em formar amplas alianças na sociedade para combater o inimigo. Tanto é assim que o Partido Comunista Brasileiro (PCB) alcançou uma imensa expressão política ao fim da Guerra, com a aprovação da anistia e o retorno à legalidade, chegando a eleger 14 deputados no pleito de dezembro de 1945, tornando Prestes o senador mais votado do país, à frente, inclusive, do ex-ditador Getúlio Vargas.

A correlação de forças que permitiu ao PCB converter-se na quarta força eleitoral do país, certamente tinha relação com a vaga revolucionária inaugurada no mundo em 1944, refletindo, de maneira distorcida, a expressão social de um partido recém-saído da clandestinidade e com grande capacidade de dirigir as lutas de massas no após-guerra. Neste contexto, a revolução social esteve perto de se concretizar em alguns países, mas o inusitado é que as democracias nascentes não foram capazes de abrigar os Partidos Comunistas (PCs), apesar de ter sido salva pela intervenção direta dos antifascistas, dos trabalhadores e dos partidos comunistas de todo o mundo. ${ }^{1} \mathrm{O}$ resultado desta tática de colaboração de classes e de defesa irrestrita da democracia inspirada por Moscou foi a expulsão dos Partidos Comunistas de diversos governos, implicando na recondução de muitos à clandestinidade. No Brasil o PCB foi excluído do jogo político tendo seu registro e seus parlamentares cassados em maio de 1947 e janeiro de 1948, respectivamente. O objetivo deste trabalho é analisar a atuação dos comunistas brasileiros diante das greves, quando estiveram imbuídos da tática de antifascismo e União Nacional orientada por Moscou, numa conjuntura de intensa movimentação política e social.

\section{LUIZ... CARLOS... PRESTES...}

Passava das 21 horas na cidade do Rio de Janeiro quando Luiz Carlos Prestes adentrou ao estádio do Vasco da Gama. Era o primeiro ato público desde que saíra da prisão após nove anos de encarceramento na

1 Cf. HOBSBAWM, E. Era dos estremos: o breve século XX: 1914-1991. São Paulo: Companhia das Letras, 1995.. p. 17. 
antiga Casa de Correção da Capital Federal. Desfilando em carro aberto, Prestes foi aplaudido delirantemente pela multidão que o aguardava e que, em uníssono, o saudava compassadamente gritando: - "Luiz... Carlos... Prestes...". Na tribuna oficial do comício, entre os vários oradores via-se o líder comunista argentino Rodolfo Ghioldi, o vice-presidente da câmara cubana Joaquim Ordoqui e o dirigente da Esquerda Democrática João Mangabeira, este último representava seu irmão Octávio, um dos personagens mais importantes do liberalismo brasileiro e que estivera exilado por vários anos nos Estados Unidos. Muitos outros convidados também se acotovelavam no grande palco do comício pomposamente chamado "o Brasil a Luiz Carlos Prestes". ${ }^{2}$

Era o dia 23 de abril de 1945, a Segunda Guerra Mundial ainda estava em curso, embora parecesse se aproximar do final, e, no Brasil do Estado Novo de Getúlio Vargas, o governo havia cedido aos apelos por anistia ampla para os prisioneiros políticos e também aos apelos pela redemocratização do país, baixando o Ato Adicional n. ${ }^{\circ}$ 9, de 28 de fevereiro de 1945. Pelo Ato estabeleciam-se eleições gerais num prazo máximo de 90 dias, passo importante para deixar para trás a ditadura e restabelecer a normalidade democrática. O pequeno homem que desfilava pelo estádio e que era ansiosamente aguardado pela multidão era apenas mais um dos libertados pelo ato da Anistia, mas não era ninguém mais, ninguém menos, do que o "Cavaleiro da Esperança”, o líder da Coluna Invicta que percorrera o Brasil nos anos 1920 pregando democracia e liberdade, era o próprio Luiz Carlos Prestes, agora secretário-geral do PCB, preso em março 1936 poucos meses após a chamada "Intentona Comunista".

O estádio do Vasco da Gama começara a encher desde as 16 horas e àquela altura já se encontrava abarrotado de pessoas fazendo com que os organizadores do comício entendessem a necessidade de fechar os portões. Cálculos do período indicam a presença de cerca de 100 mil pessoas ao evento, embora o coro dos opositores assegurasse que o São Januário não comportava tamanha multidão. Cerraram-se os portões para se evitar tumultos e possíveis contratempos. Cerraram-se também os lábios da multidão quando Prestes subiu ao palanque para falar ao povo, ato que se repetiria nos comícios seguintes, em diversas capitais do Brasil, e inspiraria o poeta Pablo Neruda a fazer poesia do acontecimento,

2 As informações sobre o comício de Prestes no estádio do Vasco da Gama, neste parágrafo e nos seguintes, foram recolhidas em: EM GRANDE comício, no campo do Vasco, declarou Luiz Carlos Prestes "O nosso programa é o partido comunista do Brasil”. A Tarde, Salvador, 23 maio 1945. Biblioteca Pública do Estado da Bahia (BPEB). Setor: Periódicos Raros. Acervo: Jornais. 
transformado em ritual. Neruda depois testemunharia dizendo que " $[\mathrm{N}]$ enhum dirigente comunista da América teve uma vida tão trágica e portentosa quanto Luís Carlos Prestes" e ainda declamaria: ${ }^{3}$

Hoy pido un gran silencio de volcanes y ríos.

Un gran silencio pido de tierras y varones.

Pido silencio a América de la nieve a la pampa.

Silencio: La Palabra al Capitán del Pueblo.

Silencio: Que el Brasil hablará por su boca.

Ao discursar para a multidão, contudo, embora certamente percebesse a dimensão histórica e apoteótica do momento de regozijo, conciliação e também conflito, o secretário-geral do Partido Comunista do Brasil não perdeu tempo e foi direto ao assunto, sendo enfático ao apontar o momento vivido pelo Partido que novamente encontrava a legalidade: "[n]esses últimos dez anos, as perseguições contra o comunismo fizeram do nosso povo o povo mais comunista da América”.

Passados dez anos desde a fracassada tentativa de se estabelecer no Brasil um Governo Nacional Popular Revolucionário através da Aliança Nacional Libertadora (ANL), Prestes discursava novamente para os trabalhadores. Também no plano internacional eram as nações comunistas e antifascistas que ultimavam seus esforços para derrotar a Alemanha e seus coligados, numa guerra que opunha o nazi-fascismo às democracias ocidentais aliadas da União Soviética. Para o líder pecebista, e muito provavelmente para os trabalhadores do Brasil e de boa parte do mundo, os comunistas viviam um momento impar, de modo que nas palavras de Prestes o comunista era "aquele que de maneira mais firme e consequente" lutava "contra o estado de coisas intolerável e injusto", negando a "miséria e [a] fome", também o "atraso e o analfabetismo", a "tuberculose e no impaludismo" e mais o "trabalho na enxada, de sol a sol", a "censura de imprensa" e as "limitações de toda ordem" enfim, eram os comunistas que negavam a "exploração do homem pelo homem" e anunciavam a boa nova de um mundo sem fascismo e, quiçá, com um longo período de paz e de boa convivência entre a URSS e as nações democráticas do ocidente.

As esperanças de Prestes tinham razão de ser, quando a URSS e os Estados Unidos cerraram fileiras para lutar contra o nazi-fascismo a partir de fins de 1941, alguma coisa parecia haver mudado no mundo.

3 NERUDA, P. Confesso que vivi: memórias. São Paulo: Círculo do Livro, [199-?]. p. 328. 
Mergulhado em duas décadas de contrarrevolução e em seis anos de uma guerra sem paralelo na história, as perspectivas dos comunistas eram animadoras. O movimento comunista internacional, que em fins da década de 1920 havia cunhado a expressão "social-fascismo" para se referir às organizações operárias vinculadas à socialdemocracia, vista como irmã gêmea do fascismo, agora se perfilava com amplos setores antifascistas com o único intuito de vencer a guerra e derrotar aquilo que consideravam como principal inimigo da humanidade, os regimes de Hitler e Mussollini. Nesse sentido, tanto os partidos comunistas de várias partes do mundo como o próprio PCB aspiravam não mais a ser o partido do proletariado, mas o "partido de todo o povo", exarando a linha política de "unidade nacional" que significava "iniciar a solução dos graves problemas econômicos e sociais” que afligiam o povo, além de chegar "por uma maneira pacifica através de eleições livres e honestas a uma Assembleia Constituinte e a reconstitucionalização democrática” almejada pelos brasileiros. Sobre socialismo, revolução e coisas do gênero, ardilosamente imputadas aos partidários da Internacional Comunista e aos pecebistas no Brasil, quase nada se falava, embora todas estas questões permanecessem lá, na política e na prática dos trabalhadores que seguiam os partidos comunistas pelo mundo. ${ }^{4}$

Mas, os brasileiros queriam mais, especialmente os trabalhadores, tanto que desde fins de 1944, principalmente a partir de 1945, tinham voltado a protagonizar diversas lutas que opunham o trabalho ao capital. Com efeito, enquanto o Estado Novo afrouxava o garrote da repressão, trabalhadores de diversos ramos da economia, como da indústria têxtil, alimentícia, de bebidas, além de bancários, ferroviários, comerciários e muitas outras categorias de diversas cidades do país, cruzavam seus braços cobrando a conta da crise que lhes tinha pesado sobre as costas ao longo da guerra. As greves voltavam a dar o ar da graça, após anos de silêncio em que as classes subalternas tiveram que enfrentar toda sorte de adversidades, especialmente carestia, escassez de gêneros e baixos salários.

Apenas para se ter uma ideia de como a vida havia piorado durante os anos que duraram a guerra, gêneros de primeira necessidade, como o açúcar, o leite, o pão e os ovos, foram substancialmente majorados desde 1939. Deste modo, na cidade do Salvador, para que um trabalhador pudesse

4 A propósito das consignas e das palavras de ordem dos comunistas em meados dos anos 1940, ver SENA JÚNIOR, Carlos Zacarias de. Os impasses da estratégia: os comunistas, o antifascismo e a revolução burguesa no Brasil. 1936-1948. São Paulo: Annablume, 2009 (especialmente os capítulos 4 e 5). 
adquirir uma libra de pão em 1945, tinha que dedicar 85 minutos de trabalho diário, enquanto que em 1939 bastavam apenas 15 minutos e 38 minutos em 1943. Para comprar um litro de leite no ano em que a guerra chegou ao fim, este mesmo trabalhador precisava labutar longos 130 minutos, contra 28 minutos em 1939 e 60 minutos em 1943. Caso fosse comprar um quilo de açúcar, seriam necessários 120 minutos em 1945, contra 38 minutos em 1939 e 80 minutos em 1943. Finalmente, para levar para casa uma dúzia de ovos, nosso lidador precisava laborar absurdos 300 minutos em 1945, ou seja, cinco horas diárias, enquanto dedicava 75 minutos em 1939 e também absurdos 290 minutos em $1943 .^{5}$

Para o desassossego dos dirigentes da nação, da classe patronal e de todos aqueles que expandiram seus negócios financiando o Estado Novo e lucrando com a guerra, os velhos protagonistas voltaram à cena, agora legitimados pelas lutas que há meses mobilizavam os trabalhadores e a juventude que das ruas exigiam a abertura de uma Segunda Frente, com a presença do Brasil nos campos de batalha. ${ }^{6}$ O próprio Getúlio Vargas, outrora o principal algoz dos comunistas, havia redimensionado sua linha e redirecionado sua política de alianças, de modo que, além de ter se convertido no "pai dos pobres" e baluarte das leis que culminaram na Consolidação das Leis Trabalhistas (CLT), agora também buscava se aproximar dos comunistas. ${ }^{7}$ Estes, contudo, apesar de virem a engrossar o coro dos que dali a algumas semanas pediriam "Constituinte com Getúlio", não estavam mais sossegados do que o governo e os patrões, muito pelo contrário.

Para os comunistas brasileiros, em que pese o fato de que apenas muito recentemente tinham deixado para trás os dias de maior dificuldade, a nova conjuntura que se inaugurava com o realinhamento de Vargas e as perspectivas de fim da guerra, com a derrota do nazi-fascismo, apesar de promissora, inspirava profundos cuidados. Tanto é assim que temendo o retorno da reação ao governo do Brasil, enquanto assistiam e, em muitos casos, dirigiam diversas categorias que deflagraram greves, pediam cautela aos trabalhadores e às vezes chegavam a se confrontar com os mais exaltados. Os pecebistas consideravam que a conjuntura mundial havia formado dois campos que agora lutavam na guerra. Seria, então, necessário que uma ordem

5 ECONOMIA: alta vertiginosa dos preços. O Momento, [S.l: s.n.], 11 jun. 1945a. BPEB. Setor: Periódicos Raros. Acervo: Jornais.

6 SENA JÚNIOR, 2009a.

7 LEVINE, R. M. Pai dos pobres: o Brasil e a Era Vargas. São Paulo: Companhia das Letras, 2001.. p. 141-160. 
de prioridades fosse considerada pelos trabalhadores que ingressavam na luta, já que a batalha pela democracia era a principal bandeira do momento, maior até do que a luta por melhores salários e outras correlatas.

Nesse sentido, ninguém menos do que Luiz Carlos Prestes foi o porta-voz da postura dos comunistas brasileiros diante da nova conjuntura. A este respeito, Prestes enfatizava que o PCB era contrário à substituição violenta do governo ao mesmo tempo em que garantia que os comunistas seriam o "esteio da ordem", tentando influir, como força independente, "num sentido unitário e pacífico para melhor solução" dos problemas que afligiam a nação. De acordo com Prestes, o objetivo do PCB era, sobretudo, a "unidade nacional”. ${ }^{8}$ E que não se tenham dúvidas de que os pecebistas falavam sério quando defendiam a ordem no contexto da construção da unidade nacional contra o nazi-fascismo e a reação.

Tanto é assim que tal posição do PCB, publicizada pelo "Cavaleiro da Esperança”, em uma entrevista a jornalistas poucos dias após sair da prisão, voltaria a aparecer no comício do Estádio do Vasco da Gama. Diante da multidão, Prestes sintetizava o programa pecebista referendado na Conferência da Mantiqueira de 1943 e que tinha sido elaborado ao longo de anos de discussão nas condições mais adversas. Ao lado das reivindicações econômicas, que eram centrais ao programa e que implicavam em reformas estruturais que apontassem para superação do atraso e dos restos feudais existentes no Brasil, também constavam demandas políticas. Tais demandas nos possibilitam compreender a tática do PCB em torno do antifascismo e da União Nacional, com ampla repercussão nas greves que alcançavam o país. Assim, enquanto reivindica o fim da legislação "caduca" que proibia a atividade legal dos partidos, mas se mostrava impotente frente ao integralismo que se reorganizava, Prestes afirma que os "comunistas e antifascistas conscientes” seriam o "esteio máximo da ordem e da lei”. ${ }^{9}$

\section{CONTRADIÇÕES HIERARQUIZADAS}

Os trabalhadores, ao que parecia, não conseguiam enxergar a situação da mesma forma que os comunistas, tanto que entabulavam greves, muitas vezes fazendo ouvidos moucos aos apelos dos seus dirigentes mais próximos. Para os pecebistas, tratava-se, certamente, de uma inversão de

8 OS COMUNISTAS preferem um candidato civil, de preferência engenheiro. A Tarde, Salvador, 27 abr. 1945. Biblioteca Pública do Estado da Bahia. Setor: Periódicos Raros. Acervo: Jornais. 
prioridades, haja vista que na "hierarquia das contradições" era a luta pela democracia e contra o nazi-fascismo o aspecto mais importante da conjuntura. Tal assertiva chegou a ganhar ares de "verdade científica", tanto que um estudioso da importância de Luiz Werneck Vianna, que consagrou um trabalho sério sobre a trajetória da modernização brasileira através das leis trabalhistas, traduziu o sentimento pecebista como um axioma somente não entendido por uma parte da classe trabalhadora que insistia em fazer greves. Tentando explicar os aspectos supervenientes da conjuntura do após-guerra, que abrigava diversas contradições, o eminente sociólogo afirmou:

Teríamos então uma formação social específica cuja ambiência conjuntural seria dada a partir de tensões que a cortavam em várias dimensões: entre o capital e o trabalho, entre a nação e o imperialismo e o latifúndio, e entre e democracia e o fascismo. Esta última, cuja matriz se radicava no sistema capitalista mundial, por sua vez, expressava as contradições interimperialistas, constituindo-se também na forma mais exasperada - pela natureza mesma do fenômeno fascista - da contradição entre o capital e o trabalho no nível mundial. Por isso, consistia na dominante em toda e qualquer formação social, subordinando as demais à sua resolução. ${ }^{10}$

Para Vianna, entre os anos de 1943 e 1945, seria essa a "informação teórica" a presidir, "o comportamento político da esquerda operária" de maneira que até mesmo, "em parte", "alguns liberais como Júlio Prestes e outros" haviam rebaixado "o nível das suas contradições com o regime em função de favorecer a mobilização econômica e político-militar contra o nazifascismo". Não obstante,

[a] partir de 45, com a obsolescência das instituições totalitárias do Estado Novo, em particular no que se refere ao controle das classes subalternas, sujeitas a um processo de inexorável exploração há cerca de uma década, precipitam-se as ações grevistas acima aludidas. ${ }^{11}$

Tais ações, para Vianna, no limite, apontavam para uma evidente reversão na hierarquia das contradições que estruturavam o período", pois "[t]endia-se a elevar para o primeiro plano a resultante do antagonismo

10 VIANNA, L. W. Liberalismo e sindicato no Brasil. Belo Horizonte: Ed. UFMG, 1999. p. 314.

11 Ibid., p. 314. 
entre o capital e o trabalho, em detrimento das tarefas políticas da redemocratização do país e da conservação do seu ritmo de industrialização". ${ }^{2}$ Ou seja, quando os trabalhadores, ou as classes subalternas, livres das amarras opressivas do Estado Novo, subvertiam a "hierarquia das contradições" e não compreendiam a "informação teórica” fundamental da conjuntura, punham em risco o caminho para a democracia e abdicavam do cumprimento das tarefas centrais da revolução brasileira, qual seja, a tarefa democrática, burguesa e de libertação nacional apontada pelos comunistas. Mais uma vez, vale à pena citar Vianna:

\begin{abstract}
Na medida em que os diferentes níveis de contradição mantinham entre si nexos internos, uma pauta operária economicista, promovendo a eclosão de aguerridos combates de classe, polarizava-se malgrado ela mesma, e não necessariamente a seu favor. Independente de suas reais motivações, a disputa econômica era tomada como contestação, trazendo o risco de reunificação das classes e elites dominantes para recomporem o sistema do seu controle político-institucional. A alternativa estava em politizar a conduta da classe operária, instalando-a compreensivelmente no painel contraditório em que atuavam as forças sociais, conduzindo-a ao objeto prioritário da luta contra o fascismo. ${ }^{13}$
\end{abstract}

Ou seja, de acordo com Vianna "politizar a conduta da classe operária” era fazê-la rebaixar o nível das suas contradições não apenas com o regime, mas com os patrões e com o capital. Talvez torná-la o esteio da ordem, como pretendiam os comunistas da época. Só não se explica é sobre quais forças sociais está se falando, já que a classe operária era justamente o sujeito mais recalcitrante ao rebaixamento de sua pauta de reivindicações. Considerando que também não eram os camponeses, nem os trabalhadores rurais ou os pequeno-burgueses das cidades, sobra apenas a "burguesia nacional", este sim um conceito perigoso, importado para o Brasil das análises da Internacional Comunista sobre a China e a Índia. De outra forma, dizer que as forças sociais são os partidos políticos, incluindo o PCB, é também confundir os sujeitos sociais com suas representações políticas.

A propósito, tal operação, que confunde sujeitos sociais e políticos, não foi incomum entre os protagonistas da história e também entre os analistas afinados com estes sujeitos, como o próprio Vianna. Para este

\footnotetext{
12 VIANNA, 1999, p. 314.

13 VIANNA, 1999, p. 314-315.
} 
campo de interpretação, os sujeitos sociais são agentes quase sempre incapazes de compreender a dimensão política da luta de classes, necessitando da organização política, neste caso do Partido Comunista, para efetuar essa transposição de consciência que o conduziria a revolução.

Obviamente que, dito assim, o importante livro de Luiz Werneck Vianna parece menor do que realmente é, haja vista que fica claro que o autor assumiu o discurso dos sujeitos do passado dando como certa a ideia de que se os trabalhadores não rebaixaram o nível das suas reivindicações ao programa mínimo do $\mathrm{PCB}$, que era, por esta ótica, o próprio programa da revolução brasileira, o problema era dos trabalhadores que não compreendiam a "informação teórica" fundamental da conjuntura. Ora, uma pequena passagem, de não mais do que duas páginas, pode não dizer muito sobre o conjunto da obra, mas denuncia os objetivos e compromissos do autor que necessita de uma grande ginástica teórica para socorrer a estratégia do $\mathrm{PCB}$, às vezes dos próprios comunistas. Embora seja necessário polemizar em torno de uma interpretação que consideramos claramente inadequada, nosso objetivo não é, de maneira alguma, desmerecer o livro Liberalismo e sindicato no Brasil escrito por Luiz Werneck Vianna, que continua sendo um dos mais importantes da literatura política, histórica e sociológica brasileira e um marco referencial na localização do processo de revolução passiva pelo qual passava o Brasil entre as décadas do liberalismo excludente e a modernidade da Era Vargas. Todavia, não podíamos seguir adiante sem este acerto de contas.

\section{OS COMUNISTAS E O PACTO POPULISTA}

Da mesma forma, em uma série de textos paradigmáticos sobre o período do pós-guerra, publicados entre 1973 e 1979, o cientista político Francisco Weffort discutiu o que chamou de "sindicalismo populista no Brasil". De acordo com o autor, a tendência à conformação de uma espécie de pacto populista no país, que toma corpo nos anos 1950, começou a ser esboçada no período imediatamente posterior à guerra, tendo por características a ideologia nacionalista, o reformismo e a conciliação de classes, e por protagonistas: Getúlio Vargas, a classe operária e as massas urbanas, além de comunistas, trabalhistas e pelegos ministerialistas alinhados ao sindicalismo oficial. A força do argumento de Weffort consiste na articulação de elementos da estrutura, da conjuntura e da agência humana para identificar "estas encruzilhadas da história em que as orientações ideológicas 
e a capacidade de ação assumem uma importância decisiva”. ${ }^{14}$ Weffort considera corretamente que a conjuntura de 1945-1946 foi "sobre determinada’ por fatores políticos”, todavia não tira as conclusões necessárias sobre as opções estratégicas das forças políticas envolvidas no processo, muito especialmente sobre o PCB que via na conciliação de classes, na democracia e no apoio à Vargas, uma necessidade tática na consecução das tarefas democráticas da revolução brasileira. ${ }^{15}$ É verdade que as implicações deste apoio, e a defesa irrestrita da "democracia" sem adjetivos, além do recorrente taticismo dos comunistas, praticamente anuviaram a dimensão estratégica ou, pelo menos, hipertrofiaram a defesa da ordem no contexto em que buscavam a revolução democrática, mas ainda assim não se pode dizer que os pecebistas tenham negligenciado as tarefas pelas quais se embatiam, ainda que tal estratégia estivesse referida a uma avaliação francamente inadequada da realidade brasileira, vista como feudal ou semifeudal. ${ }^{16}$

Em todo caso, os estudos de Weffort inauguraram uma importante vertente conceitual sobre o populismo no Brasil, muito embora necessitassem de um alargamento da base empírica para se sustentarem. Quanto a isso, atente-se para o fato de que ao contabilizar apenas oito greves "noticiadas pela imprensa”, ocorridas no Rio de Janeiro e em São Paulo, entre abril e outubro de 1945, Weffort entendeu que a sua pouca incidência revelaria a "capacidade de controle da aliança entre Vargas e os comunistas". ${ }^{17}$

Parece não haver dúvidas de que os comunistas funcionaram como um dique, represando as demandas dos trabalhadores em nome da tática do antifascismo e da União Nacional que defendiam com vistas a consecução estratégica da revolução burguesa no Brasil. Mas, parece improvável que tenham tido sucesso absoluto neste intento, especialmente porque, em muitos casos, as pressões objetivas forjavam direções improvisadas que terminavam por se confrontar com as representações políticas tradicionalmente dirigentes dos trabalhadores. Nestas situações, os confrontos eram inevitáveis e às vezes permitiam aos contendores evitar a greve em função dos objetivos outros que não os ganhos econômicos, como se supôs tivesse acontecido entre abril e outubro, ou então não impediam que os trabalhadores, ao fim e ao cabo, fossem de fato à greve,

14 WEFFORT, F. C. Origens do sindicalismo populista no Brasil (a conjuntura do após-guerra). Estudos CEBRAP, São Paulo, n. 4, abr./jun. 1973, p. 70. 
independentemente da posição das direções comunistas e trabalhistas. Em todo caso, um olhar mais atento ao registro de greves no Brasil vai muito além das oito identificadas por Weffort. ${ }^{18}$

Não obstante, à parte alguma fragilidade empírica, a base conceitual erigida por Weffort a partir de autores que não são citados, como Trotsky e Gramsci, por exemplo, permitiram ao politólogo uspiano uma grande força interpretativa, já que a maneira como compreende a política e aborda o regime estado-novista são bastante aproximadas do escopo teórico do revolucionário russo e do comunista sardo, referências fundamentais nos seus textos. ${ }^{19}$

Apesar das distintas posições que assumem no debate, os estudos de Luiz Werneck Vianna e de Francisco Weffort são de extrema relevância para uma localização das chaves conceituais e interpretativas que moveram diversos estudos no campo das ciências sociais sobre o passado recente do Brasil, e por isso permanecem clássicas na historiografia brasileira. Por se tratarem das primeiras tentativas de explicar o momento em que os comunistas brasileiros, e também de várias partes do mundo, tornaram-se o esteio da ordem burguesa e os "campeões da democracia" sem adjetivações, tais trabalhos, que não reduzem a importância de outros do mesmo período, precisam ser frequentemente revisitados. Entretanto, tais interpretações ultimamente caíram em desuso em razão dos procedimentos mais alinhados teórica e metodologicamente com a nova historiografia e com a revelação e os usos de novas fontes para a história social e política do Brasil. Como não é objetivo nosso um balanço historiográfico sobre a produção em torno do movimento comunista no Brasil, o que já esboçamos em outros trabalhos, damo-nos por satisfeitos em apenas situar os significados e as implicações políticas da conversão do PCB em "esteio máximo da ordem" na conjuntura do após-guerra na compreensão de dois importantes autores. ${ }^{20}$

18 FONTES, J. R. A Bahia de todos os trabalhadores: classe operária, sindicato e política.(1930-1947). 1997. Tese (Doutorado em História) - Faculdade de Filosofia, Letras e Ciências Humanas, Universidade de São Paulo, São Paulo, 1997; SENA JÚNIOR, C. Z. de. Os comunistas e a escalada grevista de 1945-1946 na Bahia. In: LEAL, M. das G. de A.; MOREIRA, R. N. P.; CASTELLUCCI JÚNIOR, W. (Org.). Capítulos de História da Bahia: novos enfoques, novas abordagens. São Paulo: Annablume, 2009b. p. 179-203..

19 Cf. DEMIER, F. Leon Trotsky e os estudos sobre o populismo brasileiro. Outubro, São Paulo, v. 13, p. 59$78,2005$.

20 SENA JÚNIOR, C. Z. de. Os trabalhadores e suas organizações: uma tentativa de compreender os sujeitos sociais e suas representações políticas. In: BELLINI, L.; NEGRO, A. L.; SALES SOUZA, E. Tecendo histórias: espaço, política e identidade. Salvador: EDUFBA, 2009c. p. 249-268. 


\section{UNIÃO NACIONAL}

Com a mudança de ventos na cena política mundial e com a conformação de um cenário favorável à presença dos Partidos Comunistas nos processos políticos de diversos países, os comunistas brasileiros perceberam o bom momento para colocar em pauta sua estratégia de transformar o Brasil em um país plenamente capitalista, moderno e democrático, superando os vestígios feudais e seu estado de semicolônia. Por isso, aprofundaram a tática da União Nacional e do antifascismo, definida na segunda parte da década de 1930, tornando-se honestos e consequentes defensores da democracia com vistas ao cumprimento das tarefas burguesas da revolução brasileira.

Ao se posicionar incondicionalmente na consecução dos objetivos estratégicos, o PCB propôs alianças com setores tidos por progressistas da burguesia no país, chamada de "burguesia nacional". Consequentemente, apesar de seguirem afirmando que o compromisso fundamental era com o "povo", os pecebistas delimitavam o campo de alianças em que cabia a burguesia progressista, mas se excluíam os setores populares acusados de provocação:

Lutamos e lutaremos pela unificação nacional e estendemos a mão a todos os brasileiros, mas não fazemos cambalachos nem cederemos a uma linha sequer para com os desordeiros, os golpistas, trotskistas e demais aventureiros do fascismo, que são os piores inimigos do nosso povo. ${ }^{21}$

Mas, o que era o "povo" e quem eram os "golpistas", "desordeiros" e "demais aventureiros do fascismo" que ameaçavam o movimento pela unidade e o caminho da democracia? O que estava em jogo dentro da lógica do PCB que emergia na cena política com grande expressividade arrastando multidões de trabalhadores? De que maneira os pecebistas vão transitar da antiga aspiração de ser o partido do proletariado para ser o partido de todo o povo? Como atuarão como protagonistas numa realidade conflituosa e multifacetada na sucessão de uma guerra mundial e na antecedência de um conflito novo e inaudito no mundo, a chamada Guerra Fria?

O aprofundamento da tática de União Nacional elaborada desde 1938 implicou, para os comunistas, em um realinhamento em relação ao governo de Getúlio Vargas. Este, ao que parece, após promover a legislação 
trabalhista ao primeiro plano da sua obra política, o que, em todo caso, implicava em compromissos recíprocos entre Estado e trabalhadores, dava sucessivas demonstrações de que caminhava para distender o regime de exceção inaugurado em 1937. Em vista disto, com a volta do pluripartidarismo e a (re)acomodação das forças políticas entre liberais opositores à Vargas, agora agrupados na União Democrática Nacional (UDN), liberais governistas do Partido Social Democrático (PSD) e trabalhistas do Partido Trabalhista Brasileiro (PTB) alinhados com Vargas, o PCB necessitou reajustar a sua tática, afastando-se dos "demo-liberais" da UDN, historicamente adversários do varguismo, e se aproximando dos setores do trabalhismo getulista, tanto pela base como pelo alto. Com o objetivo de garantir uma transição à democracia dentro da ordem e da tranquilidade, os pecebistas exortaram os trabalhadores a evitarem a provocação reacionária e os elementos provocadores que, supostamente, atuavam no interior do movimento operário, de maneira a não permitir retrocessos golpistas.

Atentos ao realinhamento na política brasileira, setores da imprensa liberal registraram a aproximação entre Getúlio e o PCB em torno da bandeira de União Nacional considerando-a como uma tática oportunista que aproximava os extremos:

Durante algum tempo, sobretudo depois que o Brasil entrou na guerra, uma fórmula muito preconizada em certos círculos, que pareciam desejar uma ponta para se aproximarem da ditadura, foi a chamada 'união nacional'. O fruto, ou idéia, no entanto, pecou, pois o primeiro a não querer saber de união nacional, desde que isso implicava em ceder alguma parte do seu poder discricionário, era o sr. Getulio Vargas. Ultimamente, porém, fomentada pelo próprio governo como tábua de salvação a sugestão voltou a andar pelos ares com a nova tabuleta de 'governo de coalizão'. E chegou mesmo a ganhar corpo com o telegrama do sr. Luiz Carlos Prestes ao sr. Getulio Vargas. Ostensivamente, seria uma exigência da guerra. Na realidade, mascarava a permanência da ditadura dentro de uma aliança do ditador com a esquerda e a direita, ou em linguagem mais clara com os comunistas e integralistas. ${ }^{22}$

O telegrama ao qual o jornal se refere é provavelmente um datado de 8 de abril de 1945, quando Luiz Carlos Prestes, ainda preso, congratulava-se com Getúlio pelo restabelecimento de relações com a URSS e reclamava

22 A COALISÃO. A Tarde, Salvador, 25 abr. 1945. Biblioteca Pública do Estado da Bahia. Setor: Periódicos Raros. Acervo: Jornais. 
anistia para os presos políticos "com a exclusão do meu caso pessoal, se necessário”. O que certamente incomodou o periódico liberal baiano, além do fato de que o Brasil reatava relações com a União Soviética, foram as palavras de reconhecimento de Prestes dirigidas à Vargas:

São gestos dessa altura e fatos assim concretos e de tão evidente cunho democrático que os patriotas reclamam de vossa excelência na sua qualidade de chefe da Nação e comandante supremo de suas forças armadas, neste instante em que seus filhos queridos lutam heroicamente em solo estranho pelo esmagamento total e definitivo do nazismo no mundo inteiro. ${ }^{23}$

Tábua de salvação para o governo ou tática necessária ao desenvolvimento das tarefas da revolução democrática e de libertação nacional, o fato é que a União Nacional esteve no centro da pauta política dos comunistas entre a segunda metade dos anos 1930, quando promoveram um balanço da aventura insurrecional de 1935, até pelo menos inícios de 1948, quando sucumbiram diante da Guerra Fria. A política de unidade nacional e de antifascismo adotada pelos pecebistas, não estava restrita à dimensão nacional do fenômeno e sim às condições em que a União Soviética demandava para o conjunto do movimento comunista internacional a guarda das fronteiras da "pátria do socialismo". A dissolução da Internacional Comunista em 1943 era, com efeito, uma demonstração clara de que Stalin não pretendia organizar revoluções socialistas nos países capitalistas. Quando muito, os PCs aspiravam participar de governos de coalizão com os setores progressistas das burguesias dos diversos países, numa política que remontava as resoluções sobre as frentes populares do VII Congresso da Internacional Comunista de 1935.

No que tange à aplicação da tática pelo PC brasileiro, subsumia-se toda a luta sindical e econômica aos objetivos maiores da estratégia dos comunistas que combinavam uma tática de colaboração ao objetivo estratégico cujo principal beneficiário era a própria “burguesia nacional”. Com efeito, não é de se estranhar que os pronunciamentos de Prestes abordassem, de maneira recorrente, os fatores estabilizadores da política do pós-guerra de maneira positiva, pois o objetivo era acomodar os trabalhadores dentro da ordem, o que permitiria aos comunistas um melhor posicionamento no

23 O TELEGRAMA de Prestes ao presidente da República. A Tarde, Salvador, 9 abr. 1945. BPEB. Setor: Periódicos Raros. Acervo: Jornais. 
cenário político para seguirem lutando pela superação dos restos feudais e pelo desenvolvimento do capitalismo.

\section{OS COMUNISTAS ENTRE OS TRABALHADORES}

A bem da verdade, acerca dos aspectos conflitantes com o intervencionismo estatal, contidos na legislação trabalhista, somente a questão da autonomia sindical aparecia com vigor, já que outras questões foram deixadas para trás desde a aproximação com Getúlio, efetivada, principalmente, a partir de agosto de 1943, quando da declaração de guerra ao Eixo. Os pecebistas pretendiam garantir que o Estado não intercederia nos sindicatos, mas não deixaram de ingressar maciçamente na estrutura sindical corporativa para disputar as direções junto aos pelegos e às vezes colaborarem com estes quando as greves fugiam ao controle. A este respeito, como assegura Weffort, os comunistas não apenas "não estavam interessados em confrontar suas forças com os 'pelegos' formados durante o Estado Novo como buscavam formar alianças com eles". ${ }^{24}$

Neste contexto, os pecebistas construíram uma alternativa de articulação intersindical através do Movimento de Unificação dos Trabalhadores (MUT), que viria a cumprir um papel de suma importância na organização dos sujeitos sociais na conjuntura do pós-guerra. Por vezes, era o próprio MUT o porta-voz das bandeiras comunistas, já que passou a ser o principal mediador do partido junto aos mundos do trabalho. Assim, não são raros os momentos em que o MUT recomenda cautela aos trabalhadores, como neste caso em que atentos à movimentação operária no Rio de Janeiro, observam: "o Movimento Unificador dos Trabalhadores desaconselha quaisquer movimentos grevistas e agitações que não se fundem nas justas aspirações econômicas e sociais da classe trabalhadora e do povo em geral”, e desaprovam: “Condena, assim, as agitações verificadas nesta capital e em vários Estados, denunciando seus motivos políticos, os quais são energicamente repelidos pelo proletariado organizado". ${ }^{25}$ Aqui, recorremos mais uma vez às palavras de Weffort, que afirma que o PCB e o MUT “[f]arão o possível para evitar as greves, mas não deixarão de participar quando venham a revelar-se inevitáveis”. ${ }^{26}$

WEFFORT, F. Origens do sindicalismo populista no Brasil, op. cit., p. 83

PROTESTAM os operários. A Tarde, Salvador, 6 abr. 1945. Biblioteca Pública do Estado da Bahia. Setor: Periódicos Raros. Acervo: Jornais.

WEFFORT, F. Origens do sindicalismo populista no Brasil, op. cit., p. 90. 
Mas, quais motivos políticos o MUT se refere? As agitações seriam lideradas por forças políticas estranhas ao mundo operário? Os comunistas foram, de fato, grandes adversários das greves? Considerando que as correntes ministerialistas não tinham interesse em promover greves que prejudicavam o governo e os liberais não parecem ter o reconhecimento dos trabalhadores para dirigir lutas no chão da fábrica, sobram somente os trotskistas que, em todo caso, não tinham muita influência entre os trabalhadores. Por conseguinte, pode-se considerar que, provavelmente, os comunistas combatiam contra as direções que eram improvisadas para fazer a luta que os tradicionais dirigentes da classe trabalhadora não pretendiam encampar. Dessa forma, só restava ao MUT e ao PCB pedirem cautela como forma de zelarem pela ordem e tranquilidade, dentro do espírito conciliador que caracterizava a nova época de iminente vitória da aliança URSS-EUA contra o nazi-fascismo.

Neste espírito, quando dirigiam as greves, os pecebistas faziam questão de ressaltar que estas surgiam como último recurso dos trabalhadores, mas sempre dentro dos limites da ordem, sem ameaças à propriedade privada, aos patrões e ao governo: "Pacífica e disciplinadamente, defendendo seus direitos, dentro da ordem e da tranquilidade, com uma alta consciência de classe, entraram, ontem, em greve os empregados da Companhia Linha Circular”, dizia a matéria do jornal comunista baiano O Momento, que também destacava a motivação dos operários cariocas relacionada à revogação do abono de um mês pelo governo de José Linhares, sucessor de Vargas. E prosseguiam com cuidado:

Dando magnífico exemplo patriótico, defendendo, a todo custo, a ordem e a tranqüilidade, os operários se mantinham, serenamente diante das várias instalações da CLC, como sejam o barracão de Santana, o da Barroquinha, os elevadores Lacerda e o Plano Inclinado, que também não funcionaram. Nenhum incidente se registrou. Os operários defendem a ordem e a tranqüilidade porque sabem que a desordem e o caos só interessam aos fascistas, inimigos da democracia e ferozes carrascos da classe operária. Mas ordem e tranqüilidade não significa passividade, não significa deixar que os patrões reacionários, sobretudo os patrões do capital financeiro colonizador, façam o que bem entenderem, afundando o proletariado numa miséria cada vez maior. Por isso é que os operários têm se valido de todos os recursos legais para pleitear o que é o seu direito, para encaminhar as suas mais sentidas reivindicações. ${ }^{27}$ 
Como se vê, o interesse dos pecebistas era, acima de tudo, garantir a paz e a tranquilidade, fazendo valer a máxima de que seriam o esteio máximo da ordem, em nome da União Nacional de todas as forças progressistas, a bem da democracia, do progresso da nação e da revolução democrática no Brasil.

Mas, se na maioria das vezes, os objetivos estratégicos não eram claramente enunciados, em alguns casos eles apareciam nas entrelinhas da política comunista levada adiante junto aos trabalhadores, de maneira a garantir a consecução das tarefas democráticas, desenvolver economicamente o país a partir do mercado interno para superar os resquícios do feudalismo, pois, quando os pecebistas defendiam medidas de colaboração entre as classes, o faziam "lutando pela emancipação econômica e política de nossa Pátria”; quando reivindicavam cooperação entre os trabalhadores nos sindicatos, lutavam "pela solução dos nossos problemas, dentro da ordem e do respeito mútuo entre as classes"; quando sugeriam medidas para os problemas da "paz democrática”, defendiam "uma saída pacífica da crise política brasileira”, pois consideravam que "outra qualquer solução violenta é desligada do povo”. ${ }^{28}$

O fragmento acima, retirado do discurso de Luiz Araújo, dirigente do PCB da Bahia, no encerramento do Congresso Sindical dos Trabalhadores Baianos, é ilustrativo de uma postura ostensivamente assumida pelos pecebistas frente ao mundo do trabalho. E que não se pense que os comunistas usavam da tática de União Nacional para ludibriar os incautos trabalhadores e os aliados dos setores progressistas da burguesia nacional, haja vista que são suficientemente claras as posições dos comunistas quanto ao assunto.

Ou seja, ao proletariado, cabia aceitar as condições impostas pela nova situação do mundo surgido da guerra, circunstância em que a solidariedade e a unidade eram as principais bandeiras dos trabalhadores e dos setores progressistas da burguesia, pois se aqueles tinham seus interesses confundidos com os desígnios da nação, estes não poderiam prescindir de trabalhadores "especializados, eficientes e educados", cabendo ao "governo popular" a defesa dos seus "sagrados interesses”. Quanto ao programa máximo que implicava na organização dos trabalhadores para a revolução social, nenhuma palavra.

Setor: Periódicos Raros, Acervo: Jornais.

28 OS TRABALHADORES fortalecem sua unidade. O Momento, [S.1.:s.n], 21 maio 1945c. Biblioteca Pública do Estado da Bahia. Setor: Periódicos Raros. Acervo: Jornais. 


\section{ALGUMAS PALAVRAS A GUISA DE CONCLUSÃo}

O custo da política levada à cabo pelo PCB em meados dos anos 1940 cobrou um preço alto. Após liderarem um importante processo de reorganização política dos trabalhadores que partiram para encampar reivindicações sufocadas por anos de repressão, os comunistas optaram por defender a ordem e a tranquilidade em um contexto em que o impossível parecia se tornar possível. Não há dúvidas de que os trabalhadores voltaram a acreditar nas suas próprias forças nos anos 1940, ainda mais porque por mais de uma década vivenciaram as maiores adversidades e justo naquele momento haviam dado a volta por cima. Incentivados pelas vitórias sobre os nazifascistas a partir de 1943, uma nova vaga revolucionária se abriu no mundo, recriando as condições que entre 1917 e 1921 impulsionaram os explorados e suas organizações para o protagonismo das lutas revolucionárias.

Em que pesem as condições históricas que apontavam para uma situação revolucionária em nível mundial, os comunistas, sob o controle de Moscou, apostaram na perspectiva da coexistência pacífica, depondo as armas diante de setores das burguesias que foram seus aliados contra os fascistas. No fim da guerra, contudo, quando uma nova oportunidade histórica se colocou diante dos revolucionários, suas hesitações foram maiores do que a disposição de levar adiante a tarefa pela qual lutaram por toda a vida. No final das contas, a Guerra Fria foi a resposta do ocidente à extinção da Internacional Comunista promovida por Stalin, enquanto a revolução foi novamente sufocada na maioria dos países em que se estabeleceu a democracia capitalista ou outras formas de democracia, chamadas pela historiografia de "populares".

Quanto ao PCB, sua política de colaboração de classes e de defesa irrestrita da democracia, que havia deixado de ser um componente tático para se converter quase que em uma estratégia, veio cobrar sua fatura. Inspirada pelos centros irradiadores do socialismo, a democracia aparecia agora como um fim em si mesma e não mais um caminho a ser pavimentado na construção do socialismo, especialmente para os trabalhadores que experimentavam uma grande ascensão após anos de reveses sociais e políticos, talvez parecesse surpreendente de que o Partido, no qual tinha depositado sua confiança, fosse agora o principal defensor da ordem momentânea.

Além dos operários, que foram "ensinados" a reagir com cautela frente a um histórico de opressão e exploração de longos anos de ditadura e crise econômica, foram também os comunistas do PCB a pagarem o mais alto preço pela adoção de uma tática e uma estratégia que culminariam na prostração. Quanto a isso, o PCB primeiro foi excluído do jogo político com a cassação do seu registro concedido em 1945; depois teve banido do 
parlamento os 14 deputados eleitos, além do senador Luiz Carlos Prestes. Em 1948, começaria para os comunistas da pior forma possível: com o partido e os mandatos cassados.

Quanto à classe trabalhadora, aquela que poderia vir em socorro da sua maior e mais importante representação política, esta reagiu conforme tinha aprendido com os seus dirigentes, ou seja, a classe trabalhadora reagiu com ordem e tranquilidade, ainda que uma ordem novamente excludente e uma tranquilidade nunca mais do que aparente, prenunciadora de novas tempestades. 